\title{
North Korean Labor Export to the USSR/Russia
}

Why the Project Has Survived Against All Odds

\author{
Andrei N. Lankov
}

\author{
Andrei N. Lankov \\ Kookmin University, Seoul, Republic of Korea \\ Professor \\ ORCID: 0000-0003-0876-880X \\ E-mail: andreilankov@gmail.com \\ Tel.: +82-2-910-5833 \\ Address: Kookmin University, 77 Jeongneung-ro, Seongbuk-gu, Seoul 02707, Korea \\ This work was supported by the Laboratory Program for Korean Studies through the Ministry of \\ Education of the Republic of Korea and the Korean Studies Promotion Service of the Academy \\ of Korean Studies (AKS-2019-LAB-1250001).
}

DOI: $10.31278 / 1810-6374-2020-18-3-152-176$

\begin{abstract}
The export of North Korean labor to Russia began in 1946 and continued, almost uninterrupted, until recently. The arrangements behind this labor migration project underwent dramatic revision from time to time, so we have to speak about three different periods: recruitment of North Koreans for work in fisheries in the 1940s and 1950s, dispatch of heavily controlled logging teams in the 1960s-1990s, and work of North Korean building crews, mainly on an autonomous basis, since the late 1990s. These periods reflect the way relations between the two states have been developing, and the change of their political concerns and interests. However, the underlying rationale has not changed much over the decades: the Soviet/Russian state needed cheap and docile labor, while the DPRK needed an additional source of hard currency and North Koreans were enthusiastic about getting lucrative job opportunities. On balance, both sides have been able to get what they hoped to get, and this has ensured the project's long life.
\end{abstract}


Keywords: migrant labor, USSR, the Far East, Russia, North Korea, DPRK, migration, post-socialism, logging, fishing.

ontrary to common misperception, since the collapse of
the USSR the economic interaction between the Russian
Federation and the DPRK has in fact remained quite limited. Throughout the 2008-2017 period, before UN sanctions hit the North Korean economy hard, the volume of trade between the two countries had fluctuated between a paltry $\$ 70$ million and $\$ 120$ million dollars, a mere few percent of North Korea's trade with its leading partner, China (KOTRA, 2018). It has been suggested that the official statistics systematically underestimate the scale of trade since many transactions are conducted via China due to complex logistical and other considerations. However, even if this indirect trade-of debatable scale-is factored in, Russia's role in North Korea's foreign trade volume remains marginal.

Almost at every summit, the leaders of both countries expressed their concern about the deplorable state of trade and pledged their commitment to increase its volume. However, these attempts have so far failed to produce any significant results.

The most recent-and much advertised-attempt to revive the trade activities took place in 2014-2015, largely due to Russia's strategic need to find alternatives to its erstwhile Western partners after the Crimea crisis. In June 2014, Alexander Galushka, then Russian Minister for Development of the Far East, boldly predicted a boom in economic cooperation between North Korea and Russia, and promised that by 2020 the annual volume of trade would increase tenfold, reaching $\$ 1$ billion (Sridharan, 2014). However, as we now know, this much-trumpeted good intentions ended in a completeand predictable-failure.

There are valid reasons why trade and other economic forms of interaction between these two neighboring countries remain in such a poor state. To put it simply, Russia has little or no demand for the small range of North Korean goods that can boast competitive market 
advantages, while North Korea does not have enough hard currency to purchase any significant quantity of Russian goods (Lankov, 2015).

These problems have existed for years, but in the Soviet past Moscow's geopolitical considerations sometimes prompted it to increase trade with North Korea even when it made little economic sense. This trade was viable only when it was generously subsidized by the Soviet budget, but most of the joint projects collapsed when Moscow no longer had the ability and will to subsidize them.

However, labor export/import operations are a spectacular exception to this rule. Ever since the emergence of the North Korean state in 1948 a noticeable number of workers from Korean northern territories have been employed in Soviet/Russian industries, largely in the eastern parts of the country. Neither the twists of uneasy relations between the two countries nor the vagaries of the global market have had much influence on the state of labor export.

The reasons behind such resilience are simple. Both sides have genuine economic reasons to be engaged in labor transfer, while for the vast majority of North Korean workers this is a profitable activity as well. Pressing economic needs make both sides adjust their positions and make compromises, provided this does not pose excessive political risks.

Russia has been engaged in labor import from North Korea because the country's Far East badly needs manpower. This vast territory, endowed with abundant resources, remains underpopulated. According to Russia's current administrative division, the territory known as the Far East includes nine administrative regions with a total area of 6.17 million sq. $\mathrm{km}$, which is roughly one-third of Russia's entire territory, and almost twice the size of India. However, in 2018 it had a population of mere 6.17 million-significantly lower compared to the peak year of 1990 when its population was still a meager 8.06 million (Motrich and Molodkovets, 2019 , p.55). So, the shortage of manpower and the inability to attract domestic workers from other regions of the country create problems for efficient use of the abundant natural resources of the Far East.

North Korea's interest in labor export has always been driven by economic needs as well. Its economy, increasingly lagging behind that of its neighbors and competitors, is capable of producing only a small 
number of competitive items. Meanwhile, the country has an abundant supply of cheap but high-quality manpower. As the North Korean authorities admitted recently, the country's nominal per capita GDP is merely $\$ 1,214$; that is, roughly the level of South Sudan or Lesotho (Kyodo Tsushin, 2018). Nonetheless, this very poor country boasts nearly universal literacy and a level of school attendance which rivals that of mid-income economies. Additionally, the "rice culture" of East Asia, to which North Korea belongs, is known to encourage hard work and high labor discipline. The nature of the North Korean political regime also suggests that North Korean workers are unlikely to be involved in any kind of trade unionism. In other words, North Korean workers are, as a rule, skilled, hard-working and docile people-a manager's dream in any political or social system.

Since its inception, the DPRK has been in dire need of hard currency. The North Korean government would at times not only directly appropriate a significant part of the workers' income but also their savings brought back home, in order to accumulate hard currency inside the country.

So, North Korean workers have been dispatched to countries around the world. The exact figures are not known due to the secrecy of operations, but the data available for 2012 says that there were some 15,000 North Korean workers in the Middle East; 15,000 workers in Southeast Asia; 5,000 workers in Eastern and Southern Europe; and some 30,000 workers in China (International Network, 2012, p.19). There is no data on Russia, but it is only logical to assume that this country, given its lack of human resources and North Korean government's need to export labor, would eagerly import cheap manpower from the DPRK.

The history of North Korean labor migration to Russia can be divided into three periods, each featuring its own model of organization. These models changed over time, reflecting the changes in the domestic situation in both countries and the international environment.

This research relies on different sources: academic publications, media reports, and accounts published by North Korean workers 
themselves in recent decades. It also contains an analysis of the interviews of former North Korean laborers who fled the country and currently reside in South Korea. These interviews were conducted in 2017-2018 in Seoul. Additional material was collected in Vladivostok in late 2018. The list of the interviewees (designated as R1, R2, etc.) and relevant data is shown in Table 1 below.

\section{THE 1946 MODEL: ORGANIZED RECRUITMENT FOR FISHERIES}

In the Soviet Far East of the late 1940s, the shortage of manpower remained as acute as ever, with the massive human losses in WWII further aggravating the situation. Additional problems arose with the annexation of southern Sakhalin from Japan in 1945. The entire local Japanese population was repatriated, while potential workers from other parts of the USSR showed little enthusiasm for moving to the remote island. The small number of Koreans who stayed on the island was not sufficient to meet the labor demand of the new Soviet region (Din, 2015a).

Starting from 1946, the Soviet military authorities, then in charge of the northern part of Korea, began to recruit Koreans for work in the fishing and, to a smaller degree, timber industries of the Soviet Far East. So, there developed a model of recruitment and use of labor resources from the northern part of Korea which can be called "the 1946 model."

The workers were almost exclusively males-after some deliberation the Soviet authorities decided to prohibit the workers from bringing their families to the USSR (Krushanova, 2014, p.133). The workers were to be recruited in North and South Hamgyong provinces, which, as Soviet (then classified) documents explained, faced serious food shortages in the late 1940s. The Soviets, while caring about the shortage of labor in the USSR, also assumed that the recruitment would help provide people from struggling northern Korean provinces with relatively well-paid jobs.

The recruitment was carried out by the Soviet Civil Administration, with minimal, if any, involvement of the nascent North Korean administration (Kozhemyako, 2015, pp.70-73). This practice reflected the actual discriminatory position of the local authorities during this 
period, when the Soviet military were in command of what would eventually become North Korea (or the DPRK). However, for an average North Korean the subaltern position of his state was actually beneficial: the would-be workers entered labor relations on their own initiative, with the Korean authorities unable to "cut a piece of pie" from the workers' earnings or limit their freedom of action while they were overseas.

The 1946 model was essentially an application in these North Korean territories of the Soviet internal labor recruitment practice, which in the Soviet official parlance was known as orgnabor (literally short for "organized recruitment"). This practice implied that the Soviet state agencies hired workers for very difficult and/or dangerous jobs, often in remote locations, for a certain fixed period of time. Those who signed up for orgnabor could not leave their workplace until their contract period expired, but the recruitment was voluntary, and the workers were encouraged to sign up by high wages and assorted benefits. The orgnabor system was vital for developing the vast expanses of Siberia and the Far East, especially in the 1930-1970 period (Popova, 2010, pp.63-67; Baxandall, 2004, pp.169-175).

So, in 1947 alone, some 35,000 people from the northern part of Korea arrived in the USSR through the orgnabor recruitment (Krushanova, 2014, p.133). Unfortunately, there is no data on the total number of the arrivals for the entire 1946-1949 period, but it can approximately be estimated at 50,000 to 80,000 people. The workers were overwhelmingly employed in the fishing industry: according to a recent study, in 1946 "the [recruited] Koreans were the most important source of labor for Sakhalin fisheries" (Kozhemyako, 2015, pp.70-76).

North Koreans working under the 1946 recruitment model actually enjoyed a level of individual freedom (or, at least, autonomy), which became unthinkable in later periods. To a large extent, it was possible because neither side saw the workers (or their interaction with the local population) as a likely source of ideological or political trouble.

The workers' poor Russian language skills and their everyday habits kept them isolated from the locals-and there were not many locals around in those remote locations. However, at that stage the nascent 
North Korean authorities had few, if any, ways to control the workers, and the Soviet control over them was relatively lax: they were free to move around, look for extra jobs, etc. Wages were paid directly to the workers, and they did not differ from the wages paid to Soviet nationals of comparable skills (interestingly enough, the 1946 model was the only one which did not imply wage discrimination). The workers were allowed to wire 50 percent of their earnings back home, and they could take the rest as cash once their contracts expired (Kozhemyako, 2015, pp.70-76; Krushanova, 2014, p.135).

The Soviet authorities would occasionally get worried about losing control over the large number of foreign nationals, which at that time was seen as a security threat by default. For example, in 1949 the then head of the Sakhalin border guards reported that the Koreans living in the Kuril Islands might be "used by a foreign intelligence service" and hence he would like to see them removed from this sensitive border area (Krushanova, 2014, p.137). Nonetheless, such concerns were marginal, and the seemingly omnipotent Soviet security authorities were often unable to prevent the North Korean laborers from overstaying their contract period. In essence, their position differed little from that of the locals.

In fact, the Soviet authorities were not that eager to send migrant workers back home even after their contracts expired: the temptation to retain them as a source of cheap labor must have been too difficult to resist. Moreover, around the same time, as Yulia Din's recent research has shown, the local Sakhalin authorities successfully sabotaged the planned repatriation of Koreans, whom they saw as a vital source of labor (Din, 2013). Against this background, it was no wonder that in the late 1940s some 2,500 North Korean workers were granted Soviet citizenship and thus received the right to stay in the country permanently (Krushanova, 2014, pp.136-137).

The outbreak of the Korean War in June 1950 brought labor importation to a temporary halt. Those workers who were in the USSR the moment the war broke out stayed after their contracts had expired: there was no repatriation of workers during the entire 19501953 Korean War period. By 1950, some 12,000 North Koreans still 
stayed in Sakhalin and the Kuril Islands-and there were more workers in other parts of the Far East (Din, 2015b, pp. 80-81). Only after the hostilities ended in 1953 was repatriation resumed. In many cases, the laborers did not want to go back: the Soviet Far East, in spite of being underdeveloped by Soviet standards, was seen by many North Koreans as still a better place to live than their impoverished native villages. As Igor Bezik mentions, the best way to acquire the necessary legal standing was to marry a woman who was a Soviet citizen (Bezik, 2011, p.71). In a telephone conversation with me in February 2018, Yulia Din estimated the number of such non-returnees at "many hundreds, perhaps over one thousand."

The North Korean authorities still saw the USSR as their patron and did not expect that the presence of some non-returnees would lead to any political or ideological complications. On the other hand, at that stage Pyongyang could do nothing about North Koreans staying in the USSR-all necessary pressure and surveillance measures had to be taken by the Soviet side.

After the end of the Korean War, labor importation was resumed. From July 1957, North Korean loggers were employed by timber companies near Khabarovsk, and more workers came in 1958 and 1959; a total of some 6,000 North Korean citizens stayed in the region until 1964 (Krushanova, 2006, pp.10-11).

This time the mode of organization was different. All workers were selected by the North Korean authorities; they came in groups, lived in their own segregated communities, and were employed in the timber, not the fishing industry (Troyakova, 2017, pp.82-83). Those were the signs of a new model.

\section{THE 1967 MODEL: LOGGING AND CAMP LIFE}

In May 1966, Leonid Brezhnev and Kim Il-sung held a secret summit aboard a warship cruising the Pacific in the vicinity of Vladivostok. Among other issues, the two leaders discussed a plan for a transfer of North Korean labor to the Soviet Far East. The agreement was signed in March 1967, and, with some revisions, remained operational until after the dissolution of the USSR (Troyakova, 2017, pp.82-83). 
It is worth noting that for most of the 1967-1990 period the Soviet Union remained the only importer of North Korean labor. At that time China, the major importer of the North Korean labor nowadays, was much poorer than the DPRK and had no economic reasons to accept North Korean workers-and foreigners were not welcome in China under Mao anyway. Only in the late 1980s the North Korean construction workers began to be dispatched to some friendly oil-rich countries of the Middle East, particularly to Libya.

The first Korean loggers arrived in the Khabarovsk region in 1967. According to a report by the USSR Ministry of the Interior, in April 1969 there were 12,486 North Korean workers and officials in the region (Sinichenko and Dorokhov, 2017, p.189). In 1967-1984 the agreed quota for North Korean workers was 15,000; and, as the available data indicate, the total number of workers in 1970 through 1975, as of the end of each year, was indeed just below this figure (Krushanova, 2014, p.234). In 1984 the quota was revised, so in the late 1980s the number of workers varied between 20,000 and 30,000 (Zabrovskaya, 2008).

Thus, under the 1967 model there were roughly the same number of North Korean workers as under the 1946 model (as was mentioned above, in the late 1940s the total number of workers was also in the low tens of thousands). And as we will see below, similar figures were also registered for the 2000 model.

However, there were serious differences between the 1946 and the 1967 models, which reflected the changes inside North Korea and its standing vis-à-vis the USSR. The 1967 model suggested, essentially, an interaction between the two states where the workers would be granted little autonomy. This reflected the new nature of the North Korean state-regimented, highly authoritarian and fiercely guarding its independence from its erstwhile patrons.

Under the 1946 model, the North Korean authorities did not get a cut of the workers' wages. Migrant workers voluntarily sent a significant part of their savings back home, and this benefitted the North Korean economy, but the state extracted no direct revenue from the scheme.

Under the 1967 model things were different: most of the benefits went straight to the North Korean state. The North Korean side 
was paid in kind, by high-quality timber, which it often sold on the international market, mainly to Japan. The harvested timber was divided between the USSR and North Korea, with the exact share revised from time to time (normally North Korea took about one-third of the timber supply) (Troyakova, 2017, p.84).

Throughout the entire 1967-1991 period, logging was the sole activity of the North Korean workers. They were quartered in isolated logging camps, usually located deep in the forest, far away from local villages. Notably, the first large North Korean logging camp in Chegdomen had been used as a Soviet prison camp prior to the arrival of the Korean loggers (Sinichenko and Dorokhov, 2017, p. 89).

All workers were males, and they spent their three-year contract period living military-style, their lives highly regimented and under the constant surveillance of North Korean officials, including from the security police. Interaction with the locals was not only difficult for the loggers due to the remoteness of their camps, but also strongly discouraged by their North Korean supervisors. Workers were allowed to leave their camps only in groups and could not stay outside their quarters after evening roll call. Soviet visitors were allowed inside the camps only if they were officials or had some valid reason to be there. Any kind of commercial interaction with the Russians, be it trade or individual off-the-books employment, was forbidden. Sexual liaison with a Russian woman would lead to immediate repatriation (Kim Yang-hui, 1993, p.160).

These conditions reflected the major new concerns of the North Korean authorities. On the one hand, they were attracted by the economic benefits of the project. Since a significant part of the timber was re-sold on the international market, the North Korean government effectively sold cheap labor for valuable hard currency. However, they could not ignore the potential political risks: since the early 1960s the USSR and North Korea had been drifting apart, so inside North Korea the Soviet Union began to be seen as a "revisionist" power, a source of ideological contamination. Therefore, the North Korean authorities wanted to send workers to earn money, but they also wanted to minimize their exposure to the Soviet lifestyle which, they were 
afraid, could be taken by workers as an attractive alternative to Kim Il-sung's austere and regimented Juche socialism.

The Soviet authorities did not mind this high level of surveillance. Better control over the foreigners suited them as well, and the Soviet leaders, while despising the Kim-il-sungian variety of socialism, had no intention to proselytize North Koreans. Moscow needed cheap and non-problematic workforce, that is, laborers willing to do hard and dangerous work in harsh conditions for a relatively small remuneration. Recruitment of Soviet nationals was expensive as they expected to be paid well: in the mid-1960s the average salary in the Far Eastern regions was $154 \%$ compared to the national average (Rybakovsky, 1965, p.70).

Working conditions were harsh. Most of the logging had to be done during the Siberian winter when the temperature went down to -30 or $-40 \mathrm{C}^{\circ}$. The workers lived in tiny crowded trailers, without regular access to washing facilities and laundry. The hard work itself often led to incidents, sometimes fatalities, and required a great deal of physical strength and stamina (Seo Dong-ik, 1996, pp.2, 154-166).

Nonetheless, employment in the USSR was seen as highly attractive by North Koreans. The migrant workers' major interest was, predictably, financial. In spite of the danger, hardships and restrictions, work in the Russian forests produced what was regarded in North Korea as a good monetary reward. In 1967-1984 the loggers were paid in North Korean "bank certificates" which could be used to buy highquality merchandise from communist bloc countries. The conditions were further improved in 1984-1985 when North Korean workers began to be paid a fixed monthly wage of 100 Soviet rubles (there were obligatory deductions for work clothes, blankets, food and "culture services") (Troyakova, 2017, p.83). By Soviet standards, 100 rubles was a ridiculously small wage, close to the minimum monthly wage, which in 1980 was 70 rubles (Klinova, 2014, p.139). However, by North Korean standards, this was a high income. The workers usually used their earnings to purchase durables that were freely available in Soviet shops: TV sets, fridges, wristwatches, bicycles and motorbikes. Even cooking utensils were bought in large quantities and then shipped back home, both for personal use and profitable resale. 
To the great chagrin of the Soviet authorities, North Korean workers and, especially, their supervisors augmented their income by illegal harvesting of wild resources. Some activities, like gathering wild berries for sale to the locals, were not harmful. Gathering berries was approved by the North Korean administration and was often assigned to workers who were temporarily unfit for regular logging work due to some illness (Kim Yeon-cheol, 1996, p.80).

Other activities were far less harmful. The loggers poached for medicinal herbs and, especially, musk deer (Zabrovskaya, 2008; Mikhailovsky, 2000). A former North Korean migrant worker (R2) recalls with pride the massive hunt for musk deer in the early 1990s, as the sale of the musk was a major source of income for the loggers in summer time, when they had little regular work. R2 himself smuggled some deer musk out of Russia when he returned home in 1995. The official documents of that period studied by L. Krushanova (2014) indicate that starting from 1970 the Soviet authorities were worried by the activity of North Korean poachers and the support they received from North Korean officials. However, this was obviously seen as an acceptable price to pay for the opportunity to get cheap labor.

The Soviet authorities generally tolerated smuggling. In a 2010 interview, Alexander Malashenok, a former KGB officer who in the mid-1980s was responsible for countering North Korean espionage activities, recalled how KGB officers, suspicious about the number of coffins shipped from the logging camps, which significantly exceeded the number of officially reported deaths, believed that the coffins were used as containers for smuggling prohibited goods. However, after some deliberation they decided to turn a blind eye to such activities (Ufimtsev, 2010).

By the early 1980s it became common knowledge that one work trip to the USSR would ensure many years of comfortable life for an entire North Korean family. A former logger recalled: "Since 1985 [the switch to ruble wages], the golden age of logging in the USSR began in earnest." On his way back home, a logger who had been paid 100 rubles [a month] used a fully loaded 2.4-ton truck to move consumer goods he had bought. Going to Russia was known as a way to become 
rich quickly, people would say: "TV sets, fridges, tape-recorders are hanging on the [Soviet] trees, once you are there, you make money." (Kim Seung-cheol, 1996, p.77). R9, a native from a mid-sized North Korean city bordering on China, said: "Since the 1970s many people from our city went to work in the USSR regularly. In the early 2000s there were three such families among our neighbors. In one of them, the man who went to work in the Soviet Union became an alcoholic there and died soon, but two other families became rich because of the money and goods they brought back from the USSR. I remember how one of them brought a small truck full of stuff. [...] They became very well-off."

From that time on bribing became the norm in selecting people for work in the USSR (R7, R6, Kim Seung-cheol, 2001). These bribes were usually given in kind as consumer goods (typically, a TV set or a fridge) or as a delayed payment after the trip was over and the migrant worker returned home (Kim Man-cheol, 1987).

\section{THE 2000 MODEL: CONSTRUCTION SITES AND GREAT AUTONOMY}

The collapse of the Soviet Union led to a near breakdown of trade between North Korea and the USSR, and relations between postcommunist Russia and North Korea remained quite cool for nearly a decade. Nevertheless, the export of North Korean labor continued even under very adverse circumstances. However, from around 2000 relations between the two countries began to improve, and this coincided with the beginning of the Russian economic recovery which increased demand for labor.

In August 2007, the Russian and North Korean governments signed a new agreement regulating labor migration between the two countries. In fact, the 2007 agreement was a formal approval of the arrangements which had existed for about a decade already (slowly developing in the late 1990s). That is why I would call these arrangements the 2000 model.

As was the case with earlier schemes, these arrangements were influenced by the changes in the social and economic situations in both Russia and North Korea. However, the main underlying rationale- 
the need for cheap labor on the Russian side, and the need for hard currency on the North Korean side-remained the same.

However, the structure of Russia's demand had changed. Its switch to the market economy led to the emergence of numerous individual, often small, businesses which needed a compliant, cheap and skilled workforce. But to be able to deal with smaller businesses, a more flexible approach was necessary. This meant the North Korean state's grudging acceptance that its workers would have a much higher level of exposure to post-Soviet Russian lifestyle.

In addition, the rearrangement of labor export to Russia roughly coincided with spontaneous but massive marketization of North Korea itself. Since the mid-1990s private companies began to emerge and proliferate in North Korea, and short-term informal employment became the norm. As of 2016, there were 31,500 North Koreans working in Russia. This made them the second largest group of registered foreign laborers in the country $(47,000$ Chinese constituted the largest group) (Shcherbakova, 2016). As we see, the number is not dramatically different from the figures of earlier periods.

Like in the case of the 1967 model, the would-be workers are selected by the North Korean authorities, with heavy involvement of security agencies and the party bureaucracy. On the Russian side, on the contrary, the state plays a very little part; the necessary agreements are signed by a multitude of Russian companies, largely private. Such companies sometimes actually employ North Koreans directly, but more often merely provide the necessary paperwork, while workers are employed elsewhere, in accordance with the "contract work" scheme (see below for detail). Strictly speaking, such "paper employment schemes," seemingly very common, are illegal, but as R10, a midranking Russian official, confessed: "We do not really care, since this clearly benefits both us and them." At any rate, this is a curious reversal of the 1946 model: in the 1940s the North Korean state played almost no role, while now it is the Russian state which has stepped aside.

The usual duration of contract is three years, but, unlike the 1967 model, it is easily extendable, so some workers stay on for a decade or more. Under the 2000 model, North Korean migrants are allowed to 
occasionally visit their families during the period of employment, but such trips are paid for by the workers themselves, which significantly dents their savings from earnings (R3, R4).

Only a minority of North Korean workers are still engaged in logging. In 2016 , about $80 \%$ of North Korean workers in Russia were reportedly "professional builders" (Sputnik 2016), and the others were employed in the manufacturing and timber industries. The official data basically agrees with this estimate: as of late 2016, around 22,000 North Korean workers, or some $75 \%$ of the total, were reported to be employed "in mining and construction" (Rosstat, 2017, p.161). The Far East remains the major place where the North Koreans are employed, but since 2010 North Korean workers have also been employed in western parts of Russia (R1, R6). Another novelty is the employment of North Korean females by Russian food processing and textile businesses.

Table 1. List of interviewees and relevant data

\begin{tabular}{|l|l|l|l|l|}
\hline \multicolumn{1}{|c|}{$\begin{array}{l}\text { Interviewee's } \\
\text { number }\end{array}$} & $\begin{array}{l}\text { Period of work } \\
\text { in Russia, if any }\end{array}$ & \multicolumn{1}{|c|}{ Position } & Interview date \\
\hline R1 & Around 1970 & 2014-2016 & Builder & March 3, 2018 \\
\hline R2 & Around 1960 & $\begin{array}{l}\text { The 1990s, two } \\
\text { stints }\end{array}$ & Builder & $\begin{array}{l}\text { December 2, } \\
\text { 2017 }\end{array}$ \\
\hline R3 & Around 1970 & $\begin{array}{l}\text { Five years } \\
\text { around 2010 }\end{array}$ & Builder & March 11, 2018 \\
\hline R4 & Around 1970 & 2005-2011 & $\begin{array}{l}\text { Builder, contract } \\
\text { broker }\end{array}$ & $\begin{array}{l}\text { December 10, } \\
\text { 2017 }\end{array}$ \\
\hline R5 & Around 1975 & 2007-2015 & Builder & April 2, 2018 \\
\hline R6 & Around 1970 & Around 2015 & Builder & April 8, 2018 \\
\hline R7 & Around 1965 & Around 2010 & $\begin{array}{l}\text { High-level } \\
\text { manager }\end{array}$ & April 30, 2016 \\
\hline R8 & n/a & n/a & $\begin{array}{l}\text { Chinese } \\
\text { businessman, } \\
\text { employer of NK } \\
\text { workers }\end{array}$ & January 19, 2016 \\
\hline R9 & n/a & n/a & Former NK teacher & June 5, 2017 \\
\hline R10 & n/a & $\begin{array}{l}\text { November 15, } \\
\text { Russian official }\end{array}$ \\
\hline
\end{tabular}


Perhaps the most radical difference between the 2000 and the 1967 models is the dramatic increase in the amount of freedom that North Korean migrant workers (some of them, at least) are granted. Since the mid-1990s they are often allowed to look for work on their own, and to negotiate their work conditions independently. While working in small teams, often created ad hoc to complete a particular project, workers are allowed to arrange their own accommodation, and can sometimes spend weeks without showing up at the offices of their North Korean employers/supervisors. This independent activity is described as "contract work" (cheongbu), and since 2000 around 60-70\% of all North Korean laborers in Russia have been employed through the "contract work" system.

Wages are negotiated by the workers and the brokers, and do not differ from what native-born workers of comparable skills would normally get; in this regard, the 2000 model is similar to the 1946 model. However, this wage equality is superficial. While being employed on a contract basis, North Korean workers are required to make a regular and very significant monetary contribution, known as "planned money" (gyehoekppun), to their North Korean supervisors. Importantly, we are not talking about bribing: these obligatory payments largely go to the state coffers after all necessary expenses are deducted. "Planned money" is the major way in which the North Korean state takes its considerable cut. R4 semi-jokingly explained the essence of the system: "It does not matter what exactly you are doing in Russia to make money, your [North Korean] supervisors do not care whether you're installing toilets, or doing interior work, or, say, killing people. As long as you're making money and pay on time, anything goes."

The "planned money" payments, normally made monthly, are not calculated as a percentage of a worker's earnings but constitute a fixed sum which is revised from time to time. This is another manifestation of the new flexibility and willingness to adjust to the new environment.

Agreements between North Korean workers and their Russian employers are often informal, especially in case of smaller companies, and since payments are likely to be made in cash, workers can easily underreport their earnings. This is why from the point of view of their 
supervisors, fixed payments based on rough estimates of expected earnings are the best possible alternative. In general, preference for fixed payments is typical of North Korea's emerging private economy, which, although tacitly encouraged by the authorities, remains largely informal and cash-based (Lankov, et al., 2017).

The size of the "planned money" payments varies considerably. In 2005 through 2015, a period when economic recovery resulted in a significant increase in incomes in Russia, the monthly "planned" amount varied between $\$ 450$ and $\$ 800$. Given that some 20,000 North Korean migrants (out of the average 30,000 staying in Russia) work on a "contract basis" and taking into account the administrative and other overhead expenses, one can roughly estimate that "planned money" alone provides the North Korean government with some \$100-200 million a year - tangible support for the North Korean economy.

In some cases, work opportunities can be found by the workers themselves-especially by those who speak Russian and have Russian connections (R3). However, "contract work" is usually arranged by professional intermediaries/brokers, most of whom are supervisors or interpreters. In some cases, an ordinary North Korean worker with a good command of Russian and other necessary skills (R4) can become such a professional broker-a much more profitable activity than laboring (International Network, 2012, p.48).

From the North Korean authorities' point of view, the newly granted autonomy of work in Russia increases the risk of the worker's defection-he can either run to South Korea, or stay in Russia illegally, breaking all contacts with his North Korean supervisors (and both happen from time to time). Starting from the selection stage, the authorities take measures to reduce the chances of a worker running away or engaging in unauthorized behavior. Candidates for employment overwhelmingly come from semi-privileged groups of the population-largely, from Pyongyang, and normally from families which have a reasonably good political background (songbun). In order to be selected, one has to be married and have children-obviously, on the assumption that a family man will be less likely to defect, and is easier to control (R1, R6) (International Network, 2012, pp.25, 30). 
Under the 2000 model the importance of having family members, essentially as hostages, has increased greatly now that North Korean workers have more opportunities to defect (under the 1967 model defections were hardly possible, while under the 1946 model defections were frequent, but had few political consequences).

To further minimize the risk of defection, certain rules are prescribed and, whenever practical, enforced. The workers are to surrender their passports immediately upon arrival, so normally they cannot leave Russia by using regular means of international transport. They are instructed that their interaction with the locals should be kept to a minimum, and interaction with any South Koreans is banned unconditionally (R2, R4, R6), even when North Korean workers are employed on projects conducted by or for South Korean individuals or companies (Yi Aeria and Yi Chang-ho, 2015, p.42). Workers are specifically warned against liaisons with local Russian women (R2). They are banned from using Internet-capable smartphones (R6). However, nearly all our interviewees admitted that they did breach at least some of these rules, but there was only one case when that led to problems: in 1999 a worker (R2) was found listening to a South Korean broadcast and was sent back home (but received only a minor punishment).

Not all North Korean workers in Russia are doing contract work. A significant part still work under arrangements which are reminiscent of the 1967 model: they live in dorms and are often required to march to the workplace together. They work designated shifts in groups, are provided with accommodation and food, are not required to pay "planned money," but get a small monthly allowance. Such old-style supervised group employment is common in the timber industry and manufacturing and can also be found in big construction projects. However, as workers emphasize, "contract work" is two to six times more profitable than supervised group employment, and hence much preferred (R3, R6).

The ability to earn good money is what makes migrants' work in Russia, otherwise hard and dangerous, highly attractive. As an interviewee for the 2012 report noted, "every person earns differently" 
(International Network, 2012, p.38), and this remark was also repeatedly echoed by our interviewees (R5). Nonetheless, the majority of North Korean migrant workers save an amount which goes well beyond their best expectations had they spent those years in their country. A group of Japanese and South Korean researchers in the early 2010s estimated that an average migrant working in Russia would save "from \$200 to $\$ 3,000$ a year" (Yi Aeria and Yi Chang-ho, 2015, p.33). This figure agrees with the data received in my previous research: normally, savings for the 2005-2014 period were estimated at \$1,000-2,000 per year.

This is very good money for an average North Korean: the average monthly salary in Pyongyang was a meager $\$ 40-70$ in 2018 (as said by a Westerner permanently residing in Pyongyang). This means that even a modest work contract would have a massive impact on the worker's and his family's lifestyle and future prospects. Given that working overseas gives a good chance of earning good money, there is fierce competition among the applicants, and a bribe is normally expected. In 2005-2015 the bribe a potential migrant worker was expected to pay for the opportunity to work in Russia was approximately $\$ 400-500$ (R1, R3, R4).

Typically, North Koreans invest the money they save in this way in a retail business, often run by their wives or other family members. In a typical scenario, after returning home, a worker hands a few thousand dollars to his wife who then uses the money to start an eatery or workshop, or purchase a trading license (R7, R8). One of R6's neighbors, having returned from work in Russia, opened a small private workshop producing furniture, and was doing especially well.

The 2000 model is not peculiar for Russia, but this is the country where it has taken a special form. In the Middle East, North Korean contract workers are also allowed to make some money on the side, but on the strict condition that they pay "planned money" for every day of absence from their designated worksite (with the "planned money" amount calculated on a daily basis). It is also implied that the side work is extra, made after the regular shift is over (R1, R3, R7). In China, North Korean workers are employed in processing operations and, occasionally, at restaurants, and no extra work is allowed. 
Over its nearly 75-year history, labor export from North Korea to the USSR/Russia has undergone various changes but has always remained viable. It is the economic needs of both sides that have kept it afloat.

Russia needed workforce to develop labor-intensive industries in the remote and underpopulated, but potentially rich, Far Eastern territories. North Korean workers were always on hand, ready to work for small wages, often lower than what Soviet/Russian citizens would be paid, and they were docile and law-abiding. There were few alternatives to using North Korean labor as regards the employment of foreign workers in the Russian Far East. Theoretically, given its geography and income difference, China could have served as another source of cheap labor, but for most of the time under review political concerns precluded the employment of Chinese nationals. The use of Chinese labor was considered in the late 1950s, but the subsequent crisis in relations between the USSR and China made such an opportunity unthinkable until the early 1990s. In the early 1990s the importation of the Chinese labor became less problematic, even though concerns about Chinese immigration have persisted until today. In recent years, Chinese labor has become too expensive.

Also, North Korean workers are preferable to the Chinese ones (and, for that matter, to other foreign laborers) because of their docility and desire to avoid any illegal activity, that is, one not explicitly allowed by their North Korean supervisors. This docility is largely based on the fear of harsh retribution from North Korean authorities, of whose efficiency and brutality in such matters they are perfectly aware. On the part of Russian employers and local population, such enforced docility is laudable.

In its turn, North Korea needed hard currency, and had few opportunities to get it except by engaging in international labor supply. Provision of cheap and controllable labor was a major potential source of hard currency, and until the late 1980s the Soviet/Russian Far East remained essentially the only possible destination for such export. China, which had even lower incomes and own abundant workforce, would hardly have welcomed North Korean workers, while other 
possible target areas were either too distant or politically unfriendly. The situation changed only in the late 1980s when the export of North Korean labor went global, but even then Russia remained the most attractive destination due geographical proximity and a relatively high level of income.

The pressing and mutually complementary economic needs of the sides ensured their flexibility. When the 1967 model was introduced, the Soviet side essentially accepted the de-facto extraterritoriality of North Korean workers' camps. According to the 2000 model, contract workers were allowed a certain degree of freedom and autonomy that few non-elite North Koreans had ever had, even when overseas. This created a risk of defection which, however, was seen as acceptable.

The change of models also reflected the changing relations between the two countries. The 1946 model excluded the involvement of the North Korean state authorities, which were completely dependent on and controlled by the Soviets. The 1967 model suggested interaction of the two states, each guarding its resources and interests while still accepting the importance of compromise. Under the 2000 model, the Russian state actually withdrew from the project, leaving the business of handling the workers to a multitude of largely private operators.

Finally, the mutual interests of the two states should not overshadow the fact that the project also benefited North Korean workers themselves. As long as they were willing to accept-usually harshwork conditions and ready to work hard, the project would succeed. The workers benefited especially when government control on one or both sides was more relaxed.

A number of recent UN Security Council resolutions (2371, 2375, 2379, and 2397) have essentially banned the use of North Korean labor overseas. It remains to be seen, however, to what extent the Russian authorities will abide by these new rules. The future impact of the UNSC resolutions is beyond the scope of this article, but, given the history record of labor export, there are good reasons to believe that it will be resumed at the first opportunity. The objective reasons that make it so attractive will not disappear any time soon: Russia will need cheap labor while North Korea will need hard currency and will produce only 
a small number of sellable items. So, even if all workers left Russia now (a big if), they would in all probability return, sooner or later.

\section{References}

Baxandall, P., 2004. Constructing Unemployment: The Politics of Joblessness in East and West. Burlington, VT: Ashgate.

Bezik, I., 2011. Uchastie grazhdan KNDR v hozyaīstvennom osvoenii sovetskogo Dal'nego Vostoka (1950-e-nachalo 1960-h gg.) [The Participation of the DPRK Citizens in the Economic Development of the Russian Far East (in the 1950s-the early 1960s)]. Izvestiia Vostochnogo Instituta, 17 (1), pp.64-74.

Din, Ju., 2013. Problema repatriatsii koreìtsev Yuzhnogo Sahalina v 1945-1950 gg. [The Koreans of Southern Sakhalin: The Repatriation Problem in 19451950]. Voprosy istorii, No. 8, pp.72-81.

Din, Ju., 2015a. Formirovanie i funktsionirovanie sotsial'nyh institutov po integratsii koreīskogo naseleniya Sahalina v sovetskoye obstchestvo (1945-1963) [Formation and Functioning of Social Institutions Promoting the Integration of the Sakhalin Koreans in Soviet Society (1945-1963)]. Istoria, 6 (6). Available at: <https://history.jes.su/s207987840000647-0-1/?sl=ru> [Accessed 10 May 2020].

Din, Ju., 2015b. Koreīskaya diaspora Sahalina: problema repatriatsii i integratsii $v$ sovetskoye i rossīiskoye obstchestvo [Korean Diaspora of Sakhalin: Problems of Repatriation and Integration in Soviet/Russian Society]. Juzhno-Sahalinsk: Sahalinskaya oblastnaja tipografiya.

International Network, 2012. The Conditions of the North Korean Overseas Labor. Seoul: International Network for the Human Rights of North Korean Overseas Labor, 2012.

Kim Man-cheol, 1987. Siberia Beolmoksang [A Logger in Siberia]. Jungang ilbo, 17 April.

Kim Seung-cheol, 2001. Beolmokgong, 'ilhwakcheongeum-eui kkum' [Becoming a Logger Overseas, a Dream of Instant Riches]. Choseon Ilbo, 09 August.

Kim Yang-hui, 1993. Siberia beolmokjang talchulgi-reul sseun Jang Gihong [Chang Gihong, Who Wrote a Story of His Escape from a Logging Camp in Siberia]. Bukhan, 9 (261).

Kim Yeon-cheol, 1996. Jeon jaeso imeop daepyobu 12 saeopso unjeonsu Yun Cheol [Yun Cheol, the Drive of Number 12 Production Team at the Timber Office in the USSR]. Tongil Hanguk, 10 (154), pp.76-80. 
Klinova, M., 2014. Uroven' zhizni gorodskogo naseleniya RSFSR (1946-1991)v otechestvennoi istoriografii [The Life Standards of the RSFSR Urban Population in 1946-1991, As Reflected in the Russian Historiography]. Yekaterinburg: UrGEU.

KOTRA, 2018. Bukhan daeoe muyeok donghyang [Trends in Foreign Trade of North Korea]. Seoul: KOTRA.

Kozhemyako, E., 2015. Koreīskiye rabochie kak istochnik popolneniya kadrov v rybnom hozyaīstve Sahalina posle okonchaniya Vtoroī mirovoī voinny [Korean Workers as a Source of Labor in the Sakhalin Fishing Industry after the End of WWII]. Aktualnyie voprosy obstchestvennyh nauk: Sotsiologia, Politologia, Filosofia, Istoria, No.49-50, pp.70-77.

Krushanova, L. 2014. Migratysionnaya politika SSSR na Dal'nem Vostoke (seredina 1940h-1970e) [The Migration Policy of the USSR at the Far East (mid-1940s-the 1970s)]. Vladivostok: DVO RAN.

Krushanova, L. and Vashchuk, A., 2006. Mobilizatsionnye formy popolneniya trudovyh resursov v SSSR. 1945 -1950 gg. [Mobilization Forms of Labor Resource Acquisition in the USSR, 1945 - 1950]. Rossiia i ATR, No 1, pp.5-15.

Kyodo Tsushin, 2018. North Korea's Economy Grew 3.7\% in 2017, Pyongyang Professor Estimates. The Japan Times, 13 October.

Lankov, A., 2015. Moskva-Phen'yan: chego udalos' dobitsa za god novoī druzhby s Severnoī Koreeī [Moscow-Pyuongyang: What Have Been Achieved for a Year of New Friendly Relations with North Korea]. Carnegie Moscow Center, 16 June. Available at: $<$ https://carnegie.ru/2015/06/15/ru-60402/iamt $>$ [Accessed 10 May 2020].

Lankov, A., Ward, P., Yoo, H. and Kim, J. 2017. Making Money in the State: North Korea's Pseudo-State Enterprises in the Early 2000s. Journal of East Asian Studies, Vol. 17, pp.51-67.

Mikhailovsky, B., 2000. Kabarga - ob"ekt prestupnogo biznesa [Musk Deer as the Victim of the Criminal Business]. Rossīskaia ohotnichya gazeta, 336, 20 December.

Motrich, E. and Molodkovets L., 2019. O formirovanii naseleniya i trudovyh resursov na Dal'nem Vostoke Rossii [On the Formation of Population and Labor Resources at the Russian Far East]. Ekonomicheskie i social'nye peremeny: fakty, tendentsii, prognoz, 12 (1), pp.53-68. 
Popova, I., 2010. Organizovannyī nabor kak forma privlecheniya naseleniya na Evropeīsky Sever vo vtoroī polovine 1940-h-nachale 1960-h godov [Ogrnabor as a Way to Increase Population of the European North in the Late 1940s-Early 1960s]. Izvestiya Rossīiskogo Gosudarstvennogo Pedagogicheskogo Universiteta, No.126, pp. 63-69.

Rybakovsky, L., 1965. Ispol'zovanie trudovyh resursov v raīonah Dal'nego Vostoka [The Use of Labor Resources in the Far Eastern Regions]. Khabarovsk: Khabarovskoe izdatelstvo.

Seo Dong-ik, 1996. Inmin-i saneun moseup [How People Live]. Seoul: Jaryowon.

Rosstat, 2017. Trud i zaniatost' v Rossii: statisticheckī sbornik [Labor and Employment in Russia: Statistical Data]. Moscow: Rosstat, 2017. Available at $<$ https://www.gks.ru/free_doc/doc_2017/trud_2017.pdf> [Accessed 10 May 2020]

Shcherbakova, E., 2016. Chislo inostrannyh grazhdan, imevshih deystvuyustcheye razreshenie na rabotu v Rossii, snizilos' do 174 tys. chelovek [The Number of Foreign Citizens with Effective Work Permit in Russia Decreased to 174,000]. Demoscope Weekly, No. 697-698. Available at: <http:// www.demoscope.ru/weekly/2016/0697/barom06.php> [Accessed 10 May 2020].

Sinichenko, V. and Dorokhov, Zh., 2017. Deyatel'nost' UVD Khabarovskogo kraya po obespecheniyu kontrol'a za migrantami i grazhdanami kitaīskoī i koreīskoī natsional'nosteī na sopredel'nyh s Kitayem territoriyah v 1959-1972 gg [The Activity of the Khabarovsk Region's Department for the Interior Aimed to Ensure Control over Migrants and Foreign Residents from China and Korea in the Territories Bordering with China in 1959-1972]. Vestnik arkhivista, No. 3, pp.183-197.

Sputnik, 2016. North Korean Workers in Russia: Reality Behind Western Horror Stories. Sputnik, 30 November. Available at: <https://sputniknews.com/ asia/201611301048015988-noth-korean-workers-in-russia/> [Accessed on 10 May 2020].

Sridharan, V., 2014. Russia's Vladimir Putin Eyeing Closer Ties with North Korea's Kim Jong-un. International Business Times UK, 31 March.

Troyakova, T., 2017. Rabochaia sila iz KNDR na rossiīskom Dal'nem Vostoke: istoriya i sovremennoye sostoyanie [The DPRK Labor in the Russian Far East: History and the Current Situation]. Oikumena, No. 2, pp.81-90.

Ufimtsev, Yu., 2010. Chekistskaya istoriya. Interv'yu s polkovnikom Aleksandrom Malashenkom [A CheKa Story. Interview with Colonel Alexander Malashenok]. 
Andrei N. Lankov

Konkurent.ru, 21 December. Available at <http://www.konkurent.ru/ article/8952> [Accessed 1 May 2020].

Yi Aeria and Yi Chang-ho, 2015. Yeonhaeju jiyeok bukhan nodongja-ui siltae-wa ingwon [The Position and Human Rights Situation of North Korean Workers in the Maritime Province]. Seoul: Tongil yeonguwon.

Zabrovskaya, L., 2008. KNDR-Rossiya-RK: obmen trudovymi resursami [The DPRK and Russia: The Labor Resource Exchange]. Demoscope Weekly, No. 333-334, 1963. Istoria, 6 (6). Available at <http://www.demoscope.ru/ weekly/2008/0333/analit04.php> [Accessed 21 February 2020]. 